\title{
Statin use in setting of HIV infection
}

\author{
Kenneth Lichtenstein \\ From International Symposium HIV and Emerging Infectious Diseases 2014 \\ Marseille, France. 21-23 May 2014
}

As HIV-infected individuals age due to improved antiretroviral therapy, they may be at increased risk for agerelated co-morbidities such as cardiovascular disease (CVD). Increasing numbers of these individuals are initiating statins by meeting criteria for primary cardiovascular disease prevention [1].

Previous guidelines for the general population had recommended statin therapy based on 10-year cardiovascular risk (CV risk) with goal LDL-cholesterol (LDL-C) levels depending on the risk score. The latest guidelines have changed to identify four statin-requiring risk groups. They include: 1. Patients with known atherosclerotic cardiovascular disease. 2. Individuals with LDL-C $\geq 190 \mathrm{mg} / \mathrm{dL}$ ( $\geq 4.91 \mathrm{mmol} / \mathrm{L}$ ). 3. Anyone age 40 to 75 with Type 1 or 2 diabetes mellitus (DM). 4. Individuals with a 10-year CV risk $\geq 7.5 \%$. Statin therapy is then considered moderate intensity or high intensity when achieving a $30-50 \%$ reduction or $>50 \%$ reduction in LDL-C, respectively. The guidelines define the intensity of therapy that applies [2].

In HIV infection, incident cardiovascular events are higher than that of the general population [3-5]. Clinical judgment must be brought into play when deciding whether to follow the general population guidelines for calculation of 10-year CV risk and whether to select a lower risk value at which to start therapy. Also, there are three calculators: 1 . Framingham risk calculation. 2. Pooled cohort risk calculation. 3. D*A*D risk calculation. To date, management guidelines in HIV-infection are lacking.

Providers must also be cognizant of the interactions of statins with protease-inhibitors and other drugs metabolized by the cytochrome CYP $3 \mathrm{~A}$ enzyme and adjust the doses accordingly [6,7].

Finally, statins have recently been found to be associated with incident (DM). In the general population the benefits of statin therapy outweigh the risks of incident DM [8-13]. A study in an HIV-infected population demonstrated similar incidence of DM as compared to studies in the general population [14].

National Jewish Health, Denver, Colorado, 80206, USA
Statin therapy reduces CVD events in all at risk patients. Initiation of statin therapy in HIV-infection requires additional clinical judgment due to the increase risk of CVD events and drug interactions. The cardiovascular disease benefits of statins outweigh the risks of incident DM.

Published: 23 May 2014

\section{References}

1. Grundy SM, Cleeman Jl, Merz CN, et al: National Heart, Lung, and Blood Institute; American College of Cardiology Foundation American Heart Association. Implications of recent clinical trials for the National Cholesterol Education Program Adult Treatment Panel III guidelines. Circulation 2004, 110(2):227-239.

2. Stone NJ, Robinson J, Lichtenstein AH, et al: Guideline on the treatment of blood cholesterol to reduce atherosclerotic cardiovascular risk in adults: A report of the American College of Cardiology/American Heart Association Task Force on practice guidelines. Circulation 2013, Published on line.

3. Law MG, Friis-Moller N, El-Sadr WM, et al: The use of Framingham equation to predict myocardial infarctions in HIV-infected patient: comparison with observed events in the D:A:D Study. HIV Med 2006, 7:218-230.

4. Triant VA, Lee H, Hadigan C, Grinspoon SK: Increased acute myocardial infarction rates and cardiovascular risk factors among patients with human immunodeficiency virus disease. J Clin Endocrinol Metab 2007, 92:2506-2512.

5. Hsue PY, Hunt PW, Schnell A, et al: Role of viral replication, antiretroviral therapy, and immunodeficiency in HIV-associated atherosclerosis. AIDS 2009, 23:1059-1067.

6. Aslangul $E$, Assoumou, Bittar $R$, et al: Rosuvastatin versus pravastatin in dyslipidemic HIV-1-infected patients receiving protease inhibitors: a randomized trial. AIDS 2010, 24:77-83.

7. Dube MP, Stein JH, Aberg JA, Fichtenbaum CJ, et al: Guidelines for the evaluation and management of dyslipidemia in human immunodeficiency virus (HIV)-infected adults receiving antiretroviral therapy: recommendations of the HIV Medical Association of the Infectious Disease Society of America and the Adult AIDS Clinical Trials Group. Clin Infect Dis 2003, 37:613-627.

8. Sattar N, Preiss D, Murray HM, et al: Statins and risk of incident diabetes: a collaborative metaanalysis of randomized statin trials. Lancet 2010, 375(9716):735-742.

9. Ridker PM, Danielson E, Fonseca F, et al: Cardiovascular benefits and diabetes risks of statin therapy in primary prevention: An analysis from the JUPITER Trial. N Engl J Med 2008, 359:2195-2207.

10. Sukhija R, Prayaga $S$, Maashdeh $M$, et al: Effect of statins on fasting plasma glucose in diabetic and nondiabetic patients. J Investig Med 2009, 57:495-499. 
11. Culver AL, Ockene IS, Balasubramanian R, et al: Statin use and risk of diabetes mellitus in postmenopausal women in the Women's Health Initiative. Arch Intern Med 2012.

12. Goldstein MR, Mascitelli L: Do statins cause diabetes mellitus? Curr Diab Rep 2013, 13(3):381-90.

13. Carter AA, Gomes T, Camacho X, et al: Risk of incident diabetes among patients treated with statins: population based study. BMJ 2013, 346: f2610.

14. Lichtenstein KA, Debes R, Wood K, Bozzette S, the HIV Outpatient Study investigators: 20th CROI. 2013, Abstract 767.

doi:10.1186/1471-2334-14-S2-S10

Cite this article as: Lichtenstein: Statin use in setting of HIV infection.

BMC Infectious Diseases 2014 14(Suppl 2):S10.

Submit your next manuscript to BioMed Central and take full advantage of:

- Convenient online submission

- Thorough peer review

- No space constraints or color figure charges

- Immediate publication on acceptance

- Inclusion in PubMed, CAS, Scopus and Google Scholar

- Research which is freely available for redistribution

Submit your manuscript at www.biomedcentral.com/submit
Ciomed Central 